\author{
국내 개발 이탈리안 라이그라스와 청보리 주요 품종의 생산성과 \\ 사료가치 비교 \\ 서 성·김원호·김기용·최기준·지희정·이상훈·이기원·김맹중
}

\title{
Forage Productivity and Quality of Domestic Italian Ryegrass and Barley Varieties
}

\author{
Sung Seo, Won Ho Kim, Ki Yong Kim, Gi Jun Choi, Hee Chung Ji, Sang Hoon Lee, \\ Ki Won Lee and Meing Jooung Kim
}

\begin{abstract}
This study was carried out to determine the forage production and quality of Italian ryegrass (IRG) and forage barley developed by Korea in Suwon, 2009 '10. The nine treatments were two IRG varieties (Kowinearly with early maturity and Kowinmaster with medium maturity), five barley varieties (Youngyang, Wooho, Yuyeon, Dami and Youho), and two mixtures (Kowinearly + Yuyeon and Kowinmaster + Yuyeon). The heading dates of Kowinearly and Kowinmaster were 14 May and 18 May, respectively. The growth stage of barley investigated at 22 May were late milk in Youngyang and Wooho, early dough in Dami and early to medium dough in Yuyeon and Youho. Plant length of IRG in IRG + barley mixtures was 117 $\sim 118 \mathrm{~cm}$, which was longer than those of IRG monoculture of $98 \sim 101 \mathrm{~cm}$, and no lodging was found in mixtures. The dry matter (DM) percentage at harvest was $20.7 \sim 25.4 \%$ in all treatments. The botanical composition of IRG in mixtures was $43.1 \%$. The percentage of spike per barley plant was become high according to progressed maturity, as a $35.7 \%, 44.1 \%, 54.8 \%$ and $57.2 \%$ in late milk, dough, yellowish and full ripeness stage, respectively, and the spike percentages of Youngyang and Wooho were tends to high. The crude protein (CP) content of IRG as $9.0 \sim 10.0 \%$ was higher than that of barley $(7.0 \sim 8.5 \%$ ), and the contents of NDF and ADF of barley were lower than those of IRG, and in vitro DM digestibility were $64.4 \%$ in Kowinearly, $64.1 \%$ in Kowinmaster, $64.5 \%$ in mixture, and $60.2 \%$ (Youho) to $66.4 \%$ (Wooho) in barley. The yields of DM, CP and in vitro digestible DM were high in Kowinmaster+barley mixture as a $11,508 \mathrm{~kg}, 1,046 \mathrm{~kg}$ and $7,422 \mathrm{~kg}$ per ha, respectively $(\mathrm{p}<0.05)$. However, no significant differences in forage yield were observed among cultivar of IRG, and barley, although Wooho was tends to high in digestibility and forage yield among five barley varieties. In conclusion, the mixture cultivation of IRG Kowinmaster + forage barley was recommended, because of preventing of IRG lodging, higher plant length of IRG, increasing of forage yield, and stable production. Selection of suitable winter forage species and variety for district, climate environment, and utilization type of farm was also important.
\end{abstract}

(Key words : Forage production, Mixtures, Nutritive value, Cultivar, Winter forage)

$\begin{array}{cl}\text { I . 서 론 } & \begin{array}{c}\text { 산농가나 경영체의 의지에 힘입어 사료작물 재 } \\ \text { 배면적은 크게 증가하고 있으며, 특히 논을 이 }\end{array} \\ \text { 최근 조사료 자급을 위한 정부의 정책과 생 } & \text { 용한 사료작물 생산 중심으로 양질의 조사료 }\end{array}$

농촌진흥청 국립축산과학원 (National Institute of Animal Science, RDA, Cheonan 331-801, Korea)

Corresponding author: Sung Seo, National Institute of Animal Science, RDA, Cheonan 331-801, Korea. Tel. +82-41-580-6750, Fax +82-41-580-6779, E-mail: seos9657@korea.kr 
자급은 점차 정착이 되고 있다. 답리작 사료작 물 재배면적은 1990년 43천 ha에서 2000년 48 천 ha, 2005년 70천 ha, 2008년 110천, 2009년 155천 ha로 크게 증가하여 (농식품부, 2010) 이 탈리안 라이그라스(IRG), 청보리, 호밀 등 월 동 사료작물 생산기반 구축은 조사료 자급과 친환경 양축의 청신호로 받아들여지고 있다.

2009년도 IRG의 재배면적은 52천 ha로 월동 사료작물 면적과 생산량의 $40 \%$ 이상을 점유하 고 있으며, 청보리와 호밀은 각각 34 천 ha와 40 천ha로 $26 \%$ 와 $31 \%$ 를 차지하고 있다(농식품부, 2010). 이러한 조사료 자급 확대 분위기는 우리 환경에 맞는 품종개발과 사료화 이용기술의 지 속적인 정착에 힘입고 있다(서, 2008; 최 등, 2008; Seo, 2009; 박, 2010).

지금까지 IRG는 내한성이 우수하면서 사료 가치와 수량성이 높은 품종개발을 목표로 조생 종으로는 코그린, 코스피드, 코윈어리 등 3 품 종, 중생종으로 코윈마스터 1 품종, 만생종으로 화산 101호 104호, 코위너, 화산 106호 등 6품 종으로 모두 10 품종이 개발되었으며 (최 등, 2008; Seo, 2009), 청보리는 수량성이 높으면서 기호성이 좋은 품종개발을 목표로 하여 영양, 선우, 상원, 우호, 유연, 소만, 다미, 영한, 유호 등 9품종이 육성되었다(박 등, 2010).

우리나라 양질 월동 사료작물의 두 축을 이 루는 IRG와 청보리의 품종개발에 뒤이어 생산 성과 사료가치에 대한 연구보고는 다수 있으나 두 초종을 함께 재배하여 비교한 결과는 거의 없는 실정으로, 본 연구는 국내에서 개발된 IRG와 청보리 품종 중에서 많이 재배되고 유 망한 품종을 공시하여 생산성과 사료가치를 구 명하고, 양질의 월동 사료작물 생산이용에 관 한 기술정보를 제공하고자 실시하였다.

\section{ㅍ. 재료 및 방법}

본 연구는 국내에서 개발된 이탈리안 라이그 라스(IRG, Lolium multiflorum Lam.)와 청보리
(Hordeum vulgare L.) 품종을 공시하여 국립축 산과학원 수원 사료작물시험포에서 2009 2010 년에 수행되었다. 시험품종은 IRG 2품종 (조생 종 Kowinearly, 중생종 Kowinmaster), 청보리 5 품종 (영양, 우호, 유연, 다미, 유호), 그리고 $\mathrm{IRG}+$ 청보리 혼파 2처리 (Kowinearly + 유연 혼 파, Kowinmaster + 유연 혼파) 등 9처리였다. 시 험구는 난괴법 3 반복으로 배치하였으며, 파종 은 2009년 9월 30일, 수량조사는 2010년 5월 27일에 실시하였다.

시험구당 면적은 $10 \mathrm{~m}^{2}(2.5 \times 4.0 \mathrm{~m})$ 였으며, 파 종량은 IRG는 ha당 $40 \mathrm{~kg}$, 청보리는 $200 \mathrm{~kg}$, 혼 파구는 IRG $20 \mathrm{~kg}$ + 청보리 $100 \mathrm{~kg}$ 을 청보리부 터 먼저 파종하고 $\mathrm{IRG}$ 를 파종하였다. 파종은 산파로 하였으며 파종 다음 날 트랙터를 이용 한 로울러 진압을 해 주었다. 시비량은 질소인산-칼리를 ha당 각각 $140-120-120 \mathrm{~kg}$ 을 주었 는데, 질소비료는 파종시 기비로 $50 \mathrm{~kg}$, 봄철 (3 월 29일) 추비로 $90 \mathrm{~kg}$ 을 각각 시용하였다.

처리간 출수시, 출수기, 개화기, 초장, 도복, 병해발생 등 생육특성과 생초수량, 건물수량 등을 조사하였으며 (농진청, 2003), 청보리는 품 종간 출수기 조사가 미흡하여 표기하지 않았 다. 건물수량은 각 처리구별로 $300 ~ 500 \mathrm{~g}$ 의 시 료를 취하여 $65 \sim 70^{\circ} \mathrm{C}$ 순환식 송풍건조기에서 48 72시간 건조 후 건물중량을 평량하여 건물 률을 산출한 다음 계산하였다. IRG 식생과 청 보리 이삭비율 조사는 5월 22일과 29일, 6월 5 일과 11 일 등 4 시기별로 시료를 채취한 다음 분류하고 건물중을 백분율로 표시하였다.

조단백질 함량은 Kjeldahl법 (KjeltecTM 2400 Autosampler System)을 이용하여 AOAC (1990) 법으로, neutral detergent fiber(NDF)와 acid detergent fiber (ADF)는 Goering 및 Van Soest (1970)법으로, in vitro 건물 소화율은 Tilley 및 Terry (1963)법을 Moore (1970)가 수정한 방법으 로 분석하였다.

통계분석은 SAS (2000) 프로그램 (ver. 8.01)을 이용하여 분산분석을 실시하였으며 처리간의 
Table 1. Meteorological data during growing season in Suwon

\begin{tabular}{|c|c|c|c|c|c|c|c|c|}
\hline \multirow{2}{*}{ Item } & \multicolumn{2}{|c|}{ Mean temp. $\left(\left(^{\circ} \mathrm{C}\right)\right.$} & \multicolumn{2}{|c|}{ Min. temp. $\left({ }^{\circ} \mathrm{C}\right)$} & \multicolumn{2}{|c|}{ Precipitation(mm) } & \multicolumn{2}{|c|}{ Sunshine(hr) } \\
\hline & 2010 & 30years & 2010 & 30years & 2010 & 30years & 2010 & 30years \\
\hline January & -4.4 & -3.2 & -9.6 & -7.9 & 26.9 & 23.5 & 170.2 & 166.1 \\
\hline February & 1.4 & -1.0 & -2.7 & -5.8 & 56.7 & 24.0 & 151.2 & 170.8 \\
\hline March & 4.6 & 4.5 & 0.5 & -0.7 & 78.7 & 47.0 & 140.7 & 204.5 \\
\hline April & 9.6 & 11.2 & 4.6 & 5.3 & 58.6 & 76.0 & 182.1 & 218.6 \\
\hline May & 17.1 & 16.7 & 11.9 & 11.2 & 100.7 & 94.8 & 197.2 & 233.1 \\
\hline
\end{tabular}

* Suwon Meteorological Station (2010), 30 years $(1971 \sim 2000)$.

평균비교는 Duncan의 다중검정으로 처리간의 유의성 $(\mathrm{p}<0.05)$ 을 검정하였다. 2010 년도 봄 기 상은 평년 대비 강우가 잦고 일조시간은 크게 낮아 (Table 1) 월동 사료작물의 생육에는 불리 하였을 것으로 추정된다.

\section{III. 결과 및 고찰}

\section{1. 생육특성}

국내 개발 이탈리안 라이그라스(IRG)와 청 보리 주요 품종에 대한 생육특성은 Table 2에 서 보는바와 같다. 출수시와 출수기를 살펴보
면 IRG 조생종 Kowinearly는 각각 5월 6일과 14 일, 중생종 Kowinmaster는 각각 5 월 10 일과 18 일로 조생종과 중생종의 생육차이는 4 일 정 도였다.

도복은 IRG 단파구에서 다소 관찰되었으며 청보리나 혼파구에서는 나타나지 않아 두 초종 의 혼파는 IRG의 도복방지에 효과적인 것으로 평가되었다. 청보리에서는 생육 후반부에 겉깜 부기병이 미약한 상태로 관찰되었다.

5 월 15 일과 22 일에 조사한 IRG의 생육단계 를 보면 Kowinearly는 각각 출수기와 개화초기 였으며, Kowinmaster는 각각 출수초기와 출수 후기였다. 청보리는 5월 15 일 조사에서 영양,

Table 2. Growth characteristics of Italian ryegrass(IRG) and forage barley

\begin{tabular}{|c|c|c|c|c|c|c|c|}
\hline \multirow{2}{*}{$\begin{array}{l}\text { Forage } \\
\text { species }\end{array}$} & \multirow{2}{*}{ Variety } & \multirow{2}{*}{$\begin{array}{c}\text { First } \\
\text { head- } \\
\text { ing } \\
\end{array}$} & \multirow{2}{*}{$\begin{array}{l}\text { Head- } \\
\text { ing } \\
\text { date } \\
\end{array}$} & \multirow{2}{*}{$\begin{array}{l}\text { Lodg- } \\
\text { ing } \\
(1 \sim 9)^{*}\end{array}$} & \multirow{2}{*}{$\begin{array}{l}\text { Disease } \\
(1 \sim 9)^{*}\end{array}$} & \multicolumn{2}{|c|}{ Growing stage } \\
\hline & & & & & & 15 May & 22 May \\
\hline \multirow{2}{*}{ IRG } & Kowinearly & 6 May & 14 May & $2 \sim 3$ & 1 & Mid. heading & Early bloom \\
\hline & Kowinmaster & 10 May & 18 May & $\prime \prime$ & 1 & Early heading & Late heading \\
\hline \multirow{2}{*}{$\begin{array}{c}\text { IRG+ } \\
\text { barley } \\
\text { mix. }\end{array}$} & $\begin{array}{l}\text { Kowinearly } \\
\text { +Yuyeon }\end{array}$ & - & - & 1 & 1 & - & - \\
\hline & $\begin{array}{c}\text { Kowinmaster+ } \\
\text { Yuyeon }\end{array}$ & - & - & 1 & 1 & - & - \\
\hline \multirow{5}{*}{ Barley } & Youngyang & - & - & 1 & 2 & Early bloom & Late milk \\
\hline & Wooho & - & - & 1 & 2 & $"$ & $"$ \\
\hline & Yuyeon & - & - & 1 & 2 & E. $\sim$ mid bloom & E. $\sim$ mid. dough \\
\hline & Dami & - & - & 1 & 2 & Early bloom & Early dough \\
\hline & Youho & - & - & 1 & 2 & " & E. $\sim$ mid. dough \\
\hline
\end{tabular}

*1 (strong) $\sim 9$ (weak). 
우호, 다미, 유호는 개화초기, 유연은 개화초· 중기였으며, 5월 22일 조사에서는 영양과 우호 는 유숙후기, 다미는 호숙초기, 유연과 유호는 호숙초·중기로 품종간 약간의 차이가 있었다.

출수기와 관련하여 최 등 (2008)은 Kowinearly 는 5월 6일, Kowinmaster는 5월 13일이라고 발 표하여 본 연구에 비해 5 8일 정도 생육이 빨 랐다. 청보리 출수기에서 박 등 (2008)은 유연 4월 27일, 윤 등 (2009)은 영양, 우호, 유연, 다 미에서 각각 5월 2일, 4월 29일, 4월 27일, 4월 30 일로 보고하였다. 5 월 15 일과 22 일에 조사한 청보리의 숙기는 영양과 우호에서 다소 늦고 유연과 유호에서 빠른 것으로 나타났는데 이는 박 등 (2008)의 결과와 같은 경향으로 해석된 다.

봄철 사료작물의 숙기 지연은 2010년도 봄철 이상기상 (Table 1)에 따른 월동 사료작물의 피 해상황 조사보고에서 언급된 바와 같이 (농진 청, 2010) 잦은 강우와 일조시간 부족으로 월동 사료작물의 생육이 늦어진데 기인한 것으로 추 정된다.

2. 혼파구에서 이탈리안 라이그라스의 식생 비율

이탈리안 라이그라스 $(\mathrm{IRG})$ + 청보리 혼파구 에서 IRG의 생육시기별 식생비율은 Table 3에 서 보는바와 같다. 개화초기, 개화중기, 등숙기, 성숙기에 건물중으로 산출한 $\mathrm{IRG}$ 의 식생은 각
각 $44.3 \%, 38.7 \%, 44.4 \%$ 및 $44.8 \%$ 로 평균 $43.1 \%$ 였으며, 개화이후 생육시기에 따른 IRG의 식생비율은 차이가 작았다. 또 Kowinearly+유 연 혼파구와 Kowin master+유연 혼파구 간 $\mathrm{IRG}$ 의 평균 식생비율은 각각 $42.8 \%$ 와 $43.3 \%$ 로 차이는 크지 않은 것으로 나타났다.

\section{3. 청보리의 이삭비율}

청보리의 시기별 이삭비율은 Table 4에서 보 는바와 같다. 유숙기 이후 시기별로 조사한 이 삭비율은 성숙이 진행될수록 점차 높아졌다. 혼파구에서 청보리의 이삭비율은 유숙후기, 호 숙기, 황숙기, 완숙기에서 각각 $33.7 \%, 38.2 \%$, $50.4 \%$ 및 $49.7 \%$ 로 평균 $43.0 \%$ 였으며, 청보리 단파구에서는 각각 $35.7 \%, 44.1 \%, 54.8 \%, 57.2$ $\%$ 로 평균 $47.9 \%$ 로 이삭비율은 단파구가 혼파구 에 비해 다소 높은 경향이었다. 청보리 품종별 이삭비율은 영양과 우호에서 높은 경향이었으며 유연, 다미, 유호에서 약간 낮은 경향이었다.

윤 등 (2009)은 청보리 품종별로 출수 4주째 인 황숙초기에 이삭비율을 조사한 결과, 영양 $45.8 \%$, 우호 $48.0 \%$, 유연 $38.8 \%$, 다미 $44.8 \%$ 라 고 하였으며, 서 등 (2010)은 황숙초기 유연의 이삭비율은 38.5 40.4\%였다고 하여 본 연구결 과에 비해 이삭비율은 다소 낮았다. 또 윤 등 (2009)은 영양, 우호, 유연, 다미 4품종 중 유연 에서 이삭비율이 가장 낮았다고 발표하여 본 연구결과와 같은 경향이었다.

Table 3. Percentage of botanical composition of Italian ryegrass (IRG) in IRG and forage barley mixture according to harvest stage

\begin{tabular}{cccccc}
\hline \multirow{2}{*}{ Variety } & \multicolumn{5}{c}{$\%$ of IRG (DM) } \\
\cline { 2 - 6 }$($ IRG + barley) & $\begin{array}{c}\text { Early bloom } \\
(22 \text { May })\end{array}$ & $\begin{array}{c}\text { Mid. bloom } \\
(29 \text { May })\end{array}$ & $\begin{array}{c}\text { Dough ripeness } \\
(5 \text { June })\end{array}$ & $\begin{array}{c}\text { Mature } \\
\text { (11 June) }\end{array}$ & Ave. \\
\hline \hline Kowinearly + Yuyeon & 42.4 & 34.4 & 44.3 & 50.0 & 42.8 \\
Kowinmaster + Yuyeon & 46.2 & 42.9 & 44.4 & 39.6 & 43.3 \\
\hline Average & 44.3 & 38.7 & 44.4 & 44.8 & 43.1 \\
\hline
\end{tabular}

* Harvest stage was based on Kowinearly. 
Table 4. Percentage of spike per plant of forage barley according to harvest stage

\begin{tabular}{|c|c|c|c|c|c|c|}
\hline \multirow{2}{*}{$\begin{array}{l}\text { Forage } \\
\text { species }\end{array}$} & \multirow[b]{2}{*}{ Variety } & \multicolumn{5}{|c|}{ Spike / Whole barley plant (\% of DM) } \\
\hline & & $\begin{array}{l}\text { Late milk } \\
\text { (22 May) }\end{array}$ & $\begin{array}{c}\text { Dough } \\
(29 \text { May) } \\
\end{array}$ & $\begin{array}{l}\text { Yellowish } \\
\text { (5 June) }\end{array}$ & $\begin{array}{l}\text { Full ripeness } \\
\text { (11 June) }\end{array}$ & Ave. \\
\hline \multirow{3}{*}{$\begin{array}{c}\text { IRG + } \\
\text { barley } \\
\text { mix. }\end{array}$} & Kowinearly + Yuyeon & 31.6 & 38.9 & 48.1 & 46.0 & 41.2 \\
\hline & Kowinmaster + Yuyeon & 35.7 & 37.5 & 52.7 & 53.4 & 44.8 \\
\hline & Average & 33.7 & 38.2 & 50.4 & 49.7 & 43.0 \\
\hline \multirow{6}{*}{ Barley } & Youngyang & 37.5 & 46.3 & 61.4 & 62.6 & 51.9 \\
\hline & Wooho & 37.5 & 47.5 & 55.2 & 56.9 & 49.3 \\
\hline & Yuyeon & 34.4 & 42.2 & 49.3 & 55.3 & 45.3 \\
\hline & Dami & 34.4 & 41.5 & 54.4 & 55.4 & 46.4 \\
\hline & Youho & 34.9 & 43.2 & 53.6 & 55.6 & 46.4 \\
\hline & Average & 35.7 & 44.1 & 54.8 & 57.2 & 47.9 \\
\hline
\end{tabular}

\section{4. 사료가치}

이탈리안 라이그라스(IRG)와 청보리 주요 품종에 대한 조단백질, $\mathrm{NDF}, \mathrm{ADF}$, 건물 소화 율 등 사료가치는 Table 5에서 보는바와 같다. 조단백질 함량은 IRG에서 9.0 10.0\%, 혼파구는 $7.3 \sim 9.1 \%$, 청보리는 7.0 8.5\%로 IRG에서 높은 경향이었다.

$\mathrm{NDF}$ 와 $\mathrm{ADF}$ 함량은 $\mathrm{IRG}$ 에서는 각각 $64 \%$ 와
$38 \sim 40 \%$, 혼파구는 각각 $63 \sim 64 \%, 39 \%$ 수준으 로 비슷하였으나 청보리에서는 각각 55 60\%와 $34 \sim 36 \%$ 로 IRG와 혼파구에 비해 낮았다.

건물 소화율은 Kowinearly $64.4 \%$, Kowinmaster $64.1 \%$ 로 품종간 차이는 없었으며, Kowinmaster + 유연 혼파구는 $64.5 \%$ 였으나 Kowinearly + 유 연 혼파구는 $58.6 \%$ 로 낮아 이 결과는 추후 정 밀한 분석이 필요하다고 보여진다. 청보리 품 종별 건물 소화율은 우호가 $66.4 \%$ 로 높은 경향

Table 5. The contents of crude protein (CP), neutral detergent fiber (NDF), acid detergent fiber (ADF) and in vitro dry matter digestibility (IVDMD) of Italian ryegrass (IRG) and forage barley at harvest

\begin{tabular}{ccccccc}
\hline \multirow{2}{*}{$\begin{array}{c}\text { Forage } \\
\text { species }\end{array}$} & Variety & \multicolumn{5}{c}{ Forage quality (\% of DM) } \\
\cline { 3 - 6 } & Kowinearly & CP & NDF & ADF & $\begin{array}{c}\text { Hemi- } \\
\text { cellulose }\end{array}$ & IVDMD \\
\hline \hline \multirow{2}{*}{ IRG } & Kowinmaster & 9.0 & 64.3 & 40.5 & 23.8 & 64.1 \\
\cline { 3 - 6 } $\begin{array}{c}\text { IRG + } \\
\text { barley } \\
\text { mix. }\end{array}$ & Kowinearly + Yuyeon & 7.3 & 63.7 & 39.1 & 24.6 & 58.6 \\
\hdashline & Kowinmaster + Yuyeon & 9.1 & 62.9 & 39.3 & 23.6 & 64.5 \\
\hdashline & Youngyang & 7.7 & 55.8 & 34.5 & 21.3 & 63.3 \\
Barley & Wooho & 8.5 & 58.4 & 34.0 & 24.4 & 66.4 \\
& Yuyeon & 8.3 & 57.4 & 34.8 & 22.6 & 64.8 \\
& Dami & 7.7 & 57.4 & 36.0 & 21.4 & 62.0 \\
\hline
\end{tabular}

* The samples within three replications were mixed. 
이었으며, 유연 (64.8\%), 영양 (63.3\%), 다미 (62.0 $\%)$, 그리고 유호 $(60.2 \%)$ 순이었다.

$\mathrm{IRG}$ 의 사료가치와 관련하여 최 등 (2008)은 조생종이 만생종에 비해 낮다고 하였으며, 서 (2008)와 서 등 (2010)은 일반적으로 IRG가 청 보리에 비해 조단백질 함량은 높다고 평가하였 다. 청보리 유연의 조단백질 함량은 출수 4 주 째에 7.8\% (윤 등, 2009), 출수 30일에 $8.6 \%$ (송 등, 2009), 7 8\% 수준 (서, 2008) 이었다고 하여 본 연구결과와 같은 경향이었고, 송 등 (2009) 은 출수 30 일째 조사한 유연의 건물 소화율은 $68.8 \%$ 라고 보고한 바 있다.

\section{5. 건물수량 및 가소화 건물수량}

이탈리안 라이그라스(IRG)와 청보리 주요 품종에 대한 초장, 건물률, 건물수량, 조단백질 수량, 가소화 건물수량은 Table 6에서 보는바와 같다. 수확 시 초장은 IRG $100 \mathrm{~cm}$ 내외, 청보 리 $102 \sim 110 \mathrm{~cm}$ 였으며, 혼파구에서는 청보리는 98 $100 \mathrm{~cm}$ 였으나 IRG는 단파 재배 때보다 긴 $117 \sim 118 \mathrm{~cm}$ 였다. 이는 IRG의 경우 단파재배에 서는 도복이 되나 청보리와 혼파시 도복이 방 지되어 생육은 더 좋았기 때문으로 풀이된다.

청보리 품종별 초장은 유연이 다소 짧았으며 다미와 유호에서 109 $110 \mathrm{~cm}$ 로 긴 경향이었다. 이와 관련하여 박 등 (2008)은 영양 $83 \mathrm{~cm}$, 우 호 $95 \mathrm{~cm}$, 유연 $94 \mathrm{~cm}$, 다미 $97 \mathrm{~cm}$ 를, 윤 등 (2009)은 황숙초기 수확시 영양 $110 \mathrm{~cm}$, 우호 $106 \mathrm{~cm}$, 유연 $105 \mathrm{~cm}$, 다미 $110 \mathrm{~cm}$ 를, 서 등 (2010)은 IRG와 청보리 모두 초장은 $100 \mathrm{~cm}$ 내 외로 보고한 바 있다.

건물률은 Kowinearly에서 $23.2 \%$, Kowinmaster 에서 $20.7 \%$ 였으며 Kowinearly + 유연 혼파구 $24.5 \%$, Kowinmaster + 유연 혼파구 $21.0 \%$ 였고, 청보리 품종별로는 유호를 제외하고는 24.1 $25.4 \%$ 범위였다.

건물수량은 Kowinmaster + 유연 혼파구에서 ha당 $11,508 \mathrm{~kg}$ 으로 가장 많았으며 Kowinearly
에서 $8,332 \mathrm{~kg}$ 으로 가장 적었고 $(\mathrm{p}<0.05)$, Kowinearly + 유연 혼파구와 청보리 5 품종은 $9,279 \mathrm{~kg}$ 에서 $10,709 \mathrm{~kg}$ 범위로 유의적인 차이는 인정되지 않 았다.

조단백질 수량은 Kowinmaster + 유연 혼파 구에서 $1,046 \mathrm{~kg}$ 으로 가장 많았으며 $(\mathrm{p}<0.05)$ Kowinearly + 유연 혼파구와 영양, 다미, 유호 품종에서 가장 낮았다 $(\mathrm{p}<0.05)$.

가소화 건물수량은 건물수량과 같은 결과로 Kowinmaster + 유연 혼파구에서 ha당 $7,422 \mathrm{~kg}$ 으 로 가장 많았으며 IRG Kowinearly에서 $5,363 \mathrm{~kg}$ 로 가장 적었고 $(\mathrm{p}<0.05)$, Kowinearly + 유연 혼 파구와 청보리 5 품종은 $5,583 \mathrm{~kg}$ 에서 $7,106 \mathrm{~kg}$ 으로 유의적인 차이는 없었다.

$\mathrm{IRG}$ 에서 조생종 Kowinearly와 중생종 Kowinmaster를 비교해 보면, 건물수량, 조단백질수량, 가소화건물수량 모두 유의성 있는 차이는 인정 되지 않았으나 Kowinmaster구에서 모두 많은 경향이었다. 청보리에서는 품종별 생산성 차이 는 크지 않았으나 우호에서 높은 경향이었다. 윤 등 (2009)은 청보리 품종비교에서 건물수량 과 TDN 수량은 영양보리에서 가장 많고 다음 이 우호와 다미였으며 유연에서 가장 적었다 $(\mathrm{p}<0.05)$ 고 하였는데 본 시험에서는 품종간 유 의적인 차이는 인정되지 않았으며, 박 등 (2008)은 유연의 건물수량을 10.47 톤/ha으로 보 고하여 본 연구결과와 같은 수준이었다.

이상의 결과를 종합하여 볼 때 Kowinmaster + 유연 혼파구에서 초장이 길고 $\mathrm{IRG}$ 의 도복이 나타나지 않았으며, 건물수량, 조단백질 수량, 가소화 건물수량도 각각 $11,508 \mathrm{~kg} / \mathrm{ha}, 1,046 \mathrm{~kg}$, $7,422 \mathrm{~kg}$ 으로 가장 우수한 것으로 나타나 $(\mathrm{p}<0.05)$, 혼파는 생산성 증진과 재배의 안정성 을 높이는데 유리한 것으로 평가되었다. 이와 관련하여 김 등 (2008)은 IRG와 청보리 혼파시 Kowinearly 단파 대비 건물수량은 $20 \%$ 이상, 조단백질수량은 $40 \%$ 이상, 또 영양보리 단파 대비 조단백질수량은 $60 \%$ 이상 많았다고 하였 으며, 춘파 재배한 서 등 $(2010,2011)$ 도 IRG와 
Table 6. Plant length, dry matter (DM) percentage, forage yield of DM, crude protein (CP) and in vitro digestible DM (IVDDM) of Italian ryegrass (IRG) and forage barley at harvest

\begin{tabular}{|c|c|c|c|c|c|c|}
\hline \multirow{2}{*}{$\begin{array}{l}\text { Forage } \\
\text { species }\end{array}$} & \multirow{2}{*}{ Variety } & \multirow{2}{*}{$\begin{array}{l}\text { Plant length } \\
\quad(\mathrm{cm})\end{array}$} & \multirow{2}{*}{$\begin{array}{l}\mathrm{DM} \\
(\%)\end{array}$} & \multicolumn{3}{|c|}{ Forage yield(kg/ha) } \\
\hline & & & & $\mathrm{DM}$ & $\mathrm{CP}$ & IVDDM \\
\hline \multirow{2}{*}{ IRG } & Kowinearly & 101 & 23.21 & $8,332^{\mathrm{b}}$ & $830^{\mathrm{ab}}$ & $5,363^{\mathrm{b}}$ \\
\hline & Kowinmaster & 98 & 20.70 & $9,746^{\mathrm{ab}}$ & $874^{\mathrm{ab}}$ & $6,245^{\mathrm{ab}}$ \\
\hline \multirow{2}{*}{$\begin{array}{c}\text { IRG+ } \\
\text { barley } \\
\text { mix. }\end{array}$} & $\begin{array}{c}\text { Kowinearly }+ \\
\text { Yuyeon }\end{array}$ & $\begin{array}{l}\text { IRG } 117 \\
\text { Barley } 100\end{array}$ & 24.51 & $10,033^{\mathrm{ab}}$ & $733^{\mathrm{b}}$ & $5,875^{\mathrm{ab}}$ \\
\hline & $\begin{array}{c}\text { Kowinmaster }+ \\
\text { Yuyeon }\end{array}$ & $\begin{array}{l}\text { IRG } 118 \\
\text { Barley } 98\end{array}$ & 21.02 & $11,508^{\mathrm{a}}$ & $1,046^{\mathrm{a}}$ & $7,422^{\mathrm{a}}$ \\
\hline \multirow{5}{*}{ Barley } & Youngyang & 104 & 24.11 & $9,568^{\mathrm{ab}}$ & $735^{\mathrm{b}}$ & $6,059^{\mathrm{ab}}$ \\
\hline & Wooho & 105 & 24.45 & $10,709^{\mathrm{ab}}$ & $909^{\mathrm{ab}}$ & $7,106^{\mathrm{ab}}$ \\
\hline & Yuyeon & 102 & 25.06 & $10,496^{\mathrm{ab}}$ & $869^{\mathrm{ab}}$ & $6,805^{\mathrm{ab}}$ \\
\hline & Dami & 109 & 25.38 & $10,046^{\mathrm{ab}}$ & $773^{\mathrm{b}}$ & $6,230^{\mathrm{ab}}$ \\
\hline & Youho & 110 & 29.21 & $9,279^{\mathrm{ab}}$ & $655^{\mathrm{b}}$ & $5,583^{\mathrm{ab}}$ \\
\hline
\end{tabular}

ab Means in the same column with different letter were significantly different $(\mathrm{p}<0.05)$.

청보리 혼파이용의 유리함을 강조한 바 있다.

이상의 결과로서, 월동 사료작물로 $\mathrm{IRG}$ 와 청 보리는 품종별 생산성 차이가 크지 않아 지역 특성과 재배 목적에 맞는 초종 및 품종선택과 함께 IRG(Kowinmaster 추천)+청보리 혼파가 권장되었다. 최근 건조와 습해, 일조부족 등 이 상기상이 자주 발생하는 실정을 감안할 때 양 질 조사료의 안정된 생산을 위해서는 IRG와 청보리의 혼파이용이 적극 추천된다(김 등, 2008; 서, 2008; 서 등 2010, 2011).

\section{IV. 요 약}

본 연구는 국내 개발 이탈리안 라이그라스 (IRG)와 청보리 품종의 생산성과 사료가치를 비교분석하여 영농현장에 필요한 기술정보를 제공하고자 국립축산과학원 수원 시험포장에서 2009년 9월부터 '10년 6월까지 수행하였다. 처 리내용은 IRG 2품종 (조생종 Kowinearly, 중생 종 Kowinmaster), 청보리 5품종 (영양, 우호, 유 연, 다미, 유호) 및 혼파구 (Kowinearly + 유연,
Kowinmaster + 유연) 등 9처리였다. IRG의 출수 기는 Kowin early 5월 14일, Kowinmaster 5월 18 일이었다. 5 월 22 일 조사한 청보리의 숙기는 영양과 우호는 유숙후기, 다미는 호숙초기, 유 연과 유호는 호숙초. 중기로 품종간 약간의 차 이가 있었다. IRG에서 도복이 다소 있었으나 혼파구에서는 관찰되지 않았고, 혼파구에서 IRG의 초장은 $117 \sim 118 \mathrm{~cm}$ 로 IRG나 청보리 단 파구에 비해 길었다. 수확 시 건물률은 20.7 $25.4 \%$ 였으며, 혼파구에서 시기별로 조사한 IRG 의 식생비율은 평균 $43.1 \%$ 였다. 청보리의 이삭 비율은 성숙이 진행될수록 높아지는 경향으로 유숙후기, 호숙기, 황숙기, 완숙기에서 각각 $35.7 \%, 44.1 \%, 54.8 \%, 57.2 \%$ 였으며, 품종별로는 영양과 우호에서 다소 높은 경향이었다. 조단 백질 함량은 IRG에서 $9.0 \sim 10.0 \%$ 로 높은 경향 이었으며 청보리는 $7.0 \sim 8.5 \%$, 혼파구는 7.3 $9.1 \%$ 였고, $\mathrm{NDF}$ 와 $\mathrm{ADF}$ 함량은 청보리구에서 낮은 경향이었다. 건물 소화율은 Kowinearly $64.4 \%$, Kowinmaster $64.1 \%$, Kowinmaster + 유연 혼파구는 $64.5 \%$ 였으며, 청보리는 60.2 (유호) 
$66.4 \%$ (우호) 범위로 우호에서 높은 경향이었 다. 건물수량, 조단백질 수량, 가소화 건물수량 은 Kowinmaster + 유연 혼파구에서 ha당 각각 $11,508 \mathrm{~kg}, 1,046 \mathrm{~kg}, 7,422 \mathrm{~kg}$ 으로 가장 많았으 며 $(\mathrm{p}<0.05), \mathrm{IRG}$ 와 청보리 품종별 생산성 차이 는 크지 않아 지역 특성과 재배 목적에 맞는 초종 및 품종선택과 함께 IRG (Kowinmaster)+ 청보리 혼파이용이 권장되었다.

\section{V. 인 용 문 헌}

1. 김원호, 임영철, 신재순, 이종경, 정민웅, 지희정, 서 성, 엄정열, 김제섭, 정세희, 이정복, 김영훈, 최형기, 김찬호, 임승택. 2008. 이탈리안 라이그 라스와 청보리 혼파이용 농업생산현장 신기술투 입 접목연구. 농업신기술투입 현장접목연구 결과 보고서. 농촌진흥청.

2. 농식품부. 2010. 양질 조사료 생산 확대 방안. 농 림수산식품부 축산정책과.

3. 농진청. 2003. 농업과학기술 연구조사 분석기준. 조사료. 농촌진흥청. pp. 680-684.

4. 농진청. 2010. 잦은 강우로 인한 월동 사료작물 피해상황 및 대책(안) 보고. 3월. 농촌진흥청 국 립축산과학원.

5. 박태일, 한옥규, 서재환, 박기훈. 2008. 동계 사료 작물의 신품종 육성현황 및 개발 계획. 한국초지 조사료학회 2008년도 학술심포지엄 및 46회 학 술발표회. pp. 49-73.

6. 박태일. 2010. 국내 신품종 사료작물 소개. 2010 년도 동계 사료작물 사일리지 품질경연대회. pp. 79-105.

7. 송태화, 한옥규, 윤성근, 박태일, 서재환, 김경훈, 박기훈. 2009. 사료맥류의 생육단계별 수량 및 품질 변화. 초지조사료지 29(2):129-136.
8. 서 성. 2008. 국내 조사료자원의 개발 및 이용. 한국동물자원과학회 춘계 심포지엄 (서울대, 6. 26). pp. 99-114.

9. 서 성, 정의수, 김기용, 최기준, 안종남, 한종석, 박현경, 김용수. 2010. 이탈리안 라이그라스와 청 보리의 이른 봄 단파 및 혼파 재배시 생산성과 사료가치 비교. 초지조사료지 30(2):115-120.

10. 서 성, 김원호, 김기용, 정민웅, 최기준, 박형수, 이종경. 2011. 이탈리안 라이그라스와 청보리 춘 파 재배에서 조기 수확이 수량과 사료가치 및 재생에 미치는 영향. 초지조사료지 31(1):39-46.

11. 윤성근, 박태일, 서재환, 김경훈, 송태화, 박기훈, 한옥규. 2009. 청보리 품종의 수확시기 및 사료 가치 평가. 초지조사료지 29(2):121-128.

12. 최기준, 김원호, 서 성. 2008. 한국에서 동계 사 료작물 (이탈리안 라이그라스, 청보리) 생산과 이 용. 한국초지조사료학회 2008년도 학술심포지엄 및 46회 학술발표회. pp. 17-48.

13. AOAC. 1990. Official methods of analysis (15th ed.). Association of Official Analytical Chemists, Washington DC.

14. Goering, H.K. and P.J. Van Soest. 1970. Forage fiber analysis. USDA Agric. Handbook No. 379, USDA. Washington, DC.

15. Moore, R.E. 1970. Procedure for the two-stage in vitro digestion of forage. Univ. of Florida, Dept. of Anim. Sci.

16. Seo Sung. 2009. Development of new varieties and production of forages in Korea. J. of Kor. Soc. Grassland and Forage Sci., 29 (Suppl.) 1-10.

17. Tilley, J.M.A. and R.A. Terry. 1963. A two-stage technique for the in vitro digestion of forage crops. J. Bri. Grassl. Soc. 18:104-111.

(접수일: 2011년 4월 13일, 수정일 1차: 2011년 4월 27일, 수정일 2차: 2011년 6월 8일, 게재확정일: 2011년 7월 5일) 